\title{
KOJIC ACID PRODUCTION USING MIXED CULTURES OF ASPERGILLUS ORYZAE AND ASPERGILLUS TAMARII
}

\author{
HERMAN SURYADI*, DYAH KARINA PUSPITA SUKARNA \\ Laboratory of Microbiology and Biotechnology, Faculty of Pharmacy, Universitas Indonesia, Depok, 16424, Indonesia. \\ Email: hsuryadi@farmasi.ui.ac.id
}

Received: 07 June 2018, Revised and Accepted: 27 September 2018 and 19 November 2018

\section{ABSTRACT}

Objective: This study aimed to find the optimum kojic acid fermentation conditions using combination cultures of Aspergillus oryzae and Aspergillus tamarii.

Methods: Screening of the best mixed cultures was performed using yeast extract medium with 5\% (w/v) glucose. Fermentation conditions were optimized by varying carbon and nitrogen sources, $\mathrm{pH}$ of medium, inoculum ratio, and aeration. Aeration was varied using 50 and 100 mL of medium in 100 and 250 mL Erlenmeyer flasks, respectively. Kojic acid was analyzed using thin-layer chromatography-densitometry and UV-Vis spectrophotometry.

Results: Kojic acid produced from mixed cultures yielded $0.1396 \mathrm{gg}^{-1}$, while sole cultures of $A$. oryzae and A. tamarii yielded 0.0329 gg-1 and $0.1001 \mathrm{gg}^{-1}$, respectively. Of the nine fermentation mediums, the best carbon and nitrogen sources were sucrose and yeast extract. From the three variations of $\mathrm{pH}, \mathrm{pH} 3.5$ was the optimum $\mathrm{pH}$ value. From the three ratios of inoculum concentration, a ratio of 2:3 (A. oryzae:A. tamarii) was the best ratio. Aeration was varied using 50 and $100 \mathrm{~mL}$ of medium in 100 and $250 \mathrm{~mL}$ Erlenmeyer flasks, respectively. Aeration of $100 \mathrm{~mL}$ medium in $250 \mathrm{~mL}$ Erlenmeyer flask was selected as the best aeration that produced $6.559 \mathrm{~g} / \mathrm{L}$ kojic acid.

Conclusion: The highest concentration of kojic acid was obtained by mixing cultures of $A$. oryzae and $A$. tamarii in a ratio of 2:3, using sucrose and yeast extract as the substrates at pH 3.5 and semiaerobic condition.

Keywords: Aspergillus oryzae, Aspergillus tamarii, Kojic acid, Optimization of fermentation.

(c) 2018 The Authors. Published by Innovare Academic Sciences Pvt Ltd. This is an open access article under the CC BY license (http://creativecommons. org/licenses/by/4. 0/) DOI: http://dx.doi.org/10.22159/ijap.2018.v10s1.62

\section{INTRODUCTION}

Kojic acid is a compound that is widely used in various fields, including the food, chemical, and cosmetic industries, and it is commonly used as whitening agent in cosmetic products [1]. This compound can be produced from the fermentation of several microorganisms from the Aspergillus and Penicillium genera [2].

Numerous studies associated with the production of kojic acid have generally used Aspergillus as a sole culture. However, there was a study used a combination culture of Aspergillus flavus NSH9 and A. flavus Link 44-1 for kojic acid fermentation. The results showed that kojic acid produced by mixed cultures of Aspergillus molds showed higher yield value than was produced by the sole use of Aspergillus [3]. Other studies associated with the production of kojic acid using $A$. flavus showed that aflatoxin, which is carcinogenic, was also secreted while kojic acid was produced [4]. Aflatoxins are a kind of mycotoxin and are mostly produced by A. flavus, Aspergillus parasiticus, and Aspergillus nomius [5]. Therefore, Aspergillus oryzae and Aspergillus tamarii cultures, which are generally recognized as safe sources of mold, were used in this study due to their safety approval and the absence of aflatoxin production with their use [6].

Several conditions may affect the fermentation of kojic acid, including: Carbon and nitrogen sources as substrates, $\mathrm{pH}$ values, temperature, aeration conditions, and the speed of agitation [7]. In this study, several conditions were gradually changed to determine the optimum fermentation conditions. The inoculum concentration of each mold also had to be optimized for obtaining the ideal concentration ratio. The sugar concentration was also analyzed for determining the yield value of kojic acid from the use of sole and mixed cultures.

\section{MATERIALS AND METHODS}

The two A. oryzae and A. tamarii species were obtained from IPB Culture Collection (IPBCC) in Bogor, ITB Culture Collection in Bandung, and the University Laboratory of Microbiology, Depok, Indonesia. Stock cultures were maintained on potato dextrose agar (PDA) (Difco) at $28^{\circ} \mathrm{C}$.

\section{Instruments}

The instruments used in this study were autoclave (Hirayama), oven (WTB Binder), analytical balance (Acculab), vortex mixer (Barnsted), hotplate stirrer (Corning), pH meter (Hanna), sentrifugator (Kubota 6800), incubator (Memmert), shaker (Orbit), pipettes, and other glasswares commonly used in laboratories. The instruments used for analysis were the thin-layer chromatography (TLC)-densitometer (Camag TLC Scanner 3) and UV-Vis spectrophotometer (Shimadzu).

\section{Chemicals}

PDA (Difco), glucose (Sigma-Aldrich), technical sucrose, fructose (SigmaAldrich), yeast extract (Merck), urea $\left(\mathrm{CO}\left(\mathrm{NH}_{2}\right)_{2}\right)$ (Merck), ammonium sulfate $\left(\left(\mathrm{NH}_{4}\right)_{2} \mathrm{SO}_{4}\right)$ (Merck), magnesium sulfate $\left(\mathrm{MgSO}_{4} \cdot 7 \mathrm{H}_{2} \mathrm{O}\right)$ (Merck), dicalcium phosphate $\left(\mathrm{KH}_{2} \mathrm{PO}_{4}\right)$ (Merck), ethanol (Brataco), chloride acid ( $\mathrm{HCl})$ (Merck), sodium hydroxide $(\mathrm{NaOH})\left(\right.$ Merck), ferric chloride $\left(\mathrm{FeCl}_{3}\right)$ (Merck), phenol (Merck), chloroform (Merck), methanol (Merck), toluene (Merck), formic acid (Merck), ethyl acetate (Merck), sulfuric acid $\left(\mathrm{H}_{2} \mathrm{SO}_{4}\right)$ (Merck), distilled water, and double-distilled water were used.

\section{Method of preparation}

Culture maintenance and initial fermentation medium

A. oryzae and A. tamarii colonies were streaked on an aseptic agar slope of PDA medium then incubated at $28^{\circ} \mathrm{C}$ for 7 days. Most cultures were stored 
as stock cultures at $4^{\circ} \mathrm{C}$ and the rest, used as working cultures, were stored at $30^{\circ} \mathrm{C}$. Stock culture maintenance was performed every 2 months while working culture was performed every 2 weeks [8,9]. For screening, initial fermentation medium was prepared which contained $(\mathrm{w} / \mathrm{v}): 5 \%$ glucose, $0.25 \%$ yeast extract, $0.10 \% \mathrm{KH}_{2} \mathrm{PO}_{4}$, and $0.05 \% \mathrm{MgSO}_{4} .7 \mathrm{H}_{2} \mathrm{O}$.

\section{Preculture/inoculum development}

After incubation for 7 days, a volume of $1.0 \mathrm{~mL}$ double-distilled water was added into the mold cultures on the agar medium. The spores were scraped and aseptically transferred into a reaction tube containing $9.0 \mathrm{~mL}$ double-distilled water and then homogenized using a vortex for obtaining spore suspension with 10 -times dilution. $50 \mathrm{~mL}$ of pre-culture medium containing sucrose and yeast extract (YES) was poured into a $100 \mathrm{~mL}$ flask and $5.0 \mathrm{~mL}$ of spore suspension was added. They were then incubated for 2 days at room temperature with $180 \mathrm{rpm}$ agitation [8].

\section{Screening of best mixed cultures}

A total of $5 \%(\mathrm{v} / \mathrm{v})$ of each inoculum was mixed and suspended with $2 \mathrm{~mL}$ of an initial fermentation medium containing glucose, yeast extract, $\mathrm{KH}_{2} \mathrm{PO}_{4}$, and $\mathrm{MgSO}_{4} .7 \mathrm{H}_{2} \mathrm{O}$ in the reaction tube. They were incubated at room temperature for 7 days with $180 \mathrm{rpm}$ agitation. The identification of kojic acid was performed using $1 \% \mathrm{FeCl}_{3}$ reagent. A total of $200 \mu \mathrm{L}$ of fermented cultures were added to a drop plate and then administered with one drop of $1 \% \mathrm{FeCl}_{3}$. The cultures with a reddish-brown color, those that were more concentrated, and those which produced most cell biomass were selected as the best mixed cultures [4].

\section{Preparation of the Kojic Acid Standard Calibration Curve}

The standard solution of kojic acid was prepared with a concentration ranging from 20 to $80 \mathrm{ppm}$ using chloroform: methanol (2:1). $2 \mu \mathrm{L}$ of each concentration was spotted onto the silica gel plate. The plate was eluted with toluene: ethyl acetate: formic acid (3:6:1). The eluted plate was dried and the absorbance was measured by densitometer using a D2 lamp, UV-Vis detector, and the maximum wavelength was determined. On the basis of the maximum wavelength obtained, the calibration curve was made between the area and the concentration of the solution. A linear regression equation and correlation coefficient (r) were obtained for kojic acid determination [4].

\section{Optimization of fermentation conditions}

\section{Variation of carbon and nitrogen sources}

Kojic acid fermentation was carried out using a $50 \mathrm{~mL}$ mixture of three different carbon sources $5 \%$ of glucose, sucrose, and fructose, respectively) and three different nitrogen sources $(0.25 \%$ of yeast extract, urea, and ammonium sulfate, respectively) in a $100 \mathrm{~mL}$ flask. A total of $10 \%(\mathrm{v} / \mathrm{v})$ inoculum was suspended into each fermentation medium. They were incubated at room temperature for 9 days with $180 \mathrm{rpm}$ agitation. The cell biomass and kojic acid concentration were determined.

\section{Variation of $\mathrm{pH}$ medium}

The $\mathrm{pH}$ variations in the fermentation processes with the selected medium were as follows: $3.5,4.5$, and 5.5 . $\mathrm{pH}$ values were adjusted by adding a few drops of $\mathrm{HCl} 1 \mathrm{~N}$ on the fermentation medium [10]. They were incubated at room temperature for 9 days with $180 \mathrm{rpm}$ agitation. The cell biomass and kojic acid concentration were determined.

\section{Variation of inoculum concentration ratio}

For obtaining the ideal inoculum concentration ratio of $A$. oryzae and $A$. tamarii, ratios of $1: 1,3: 2$, and $2: 3$ were prepared. The cell biomass and kojic acid concentration were determined.

\section{Variation of aeration conditions}

A total of $10 \%(\mathrm{v} / \mathrm{v})$ inoculum with selected inoculum concentration ratio was suspended with selected fermentation medium in various aeration volumes. For aeration optimization, the volume of medium used was varied: $50 \mathrm{~mL}$ in $100 \mathrm{~mL}$ flask and $100 \mathrm{~mL}$ in $250 \mathrm{~mL}$ Erlenmeyer flask. They were incubated for 9 days with $180 \mathrm{rpm}$ agitation [11]. The cell biomass and kojic acid concentration were determined.

\section{Quantitative analysis of kojic acid}

\section{Kojic acid determination}

Each fermentation culture was centrifuged for $15 \mathrm{~min}$ at $6500 \mathrm{rpm}$ at room temperature; $200 \mu \mathrm{L}$ of each supernatant was drawn out and dissolved in $2 \mathrm{~mL}$ of chloroform: methanol (2:1). A total of $1 \mu \mathrm{L}$ of each sample was spotted on a silica plate. The plate was eluted, dried, and analyzed for obtaining the area. The concentration of kojic acid was obtained by plotting the area into the regression equation of the kojic acid standard solution [8].

\section{Cell biomass separation and determination of dry cell weight}

The mycelial pellet was washed with distilled water [10], and then, the filter paper with the mycelial pellet was dried in the oven at $105^{\circ} \mathrm{C}$ and weighed to a constant weight. Dry cell weight was determined by the difference between the pre-weighed filter paper and its weight after (with cell biomass deposits) [4].

\section{Qualitative analysis of kojic acid}

The UV-Vis spectrophotometry and spectrocolorimeter method were used for analyzing kojic acid qualitatively. Using the UV-Vis Spectrophotometry, a standard solution of kojic acid was made with a concentration of $25.2 \mathrm{ppm}$. The solution absorbance was measured at a wavelength of $200-400 \mathrm{~nm}$ and the maximum wavelength was determined; $1 \mathrm{~mL}$ of the fermented filtrate was transferred into a $10 \mathrm{~mL}$ measuring flask and dissolved in distilled water for analyzing kojic acid in fermentation culture; $1 \mathrm{~mL}$ of this solution was transferred into a $50 \mathrm{~mL}$ measuring flask and distilled water was adjusted until $50 \mathrm{~mL}$. The maximum wavelength was determined based on the absorbance obtained and compared with the standard maximum wavelength [8].

Using the spectrocolorimeter method, a standard solution of kojic acid was prepared with $100.8 \mathrm{ppm}$ concentration. Up to $8 \mathrm{~mL}$ of standard solution was added, with $1 \mathrm{~mL}$ of $1 \% \mathrm{FeCl}_{3}$ solution. The solution absorbance was measured at a wavelength of 400-700 $\mathrm{nm}$ and the maximum wavelength determined. For analyzing kojic acid in fermentation culture, $1 \mathrm{~mL}$ filtrate was transferred into a $50 \mathrm{~mL}$ measuring flask and diluted with distilled water. Next, $8 \mathrm{~mL}$ of the solution was transferred and mixed with $1 \mathrm{~mL}$ of $1 \% \mathrm{FeCl}_{3}$ solution. The absorbance of the solution was measured, and its maximum wavelength was determined and then compared with the standard maximum wavelength [8].

\section{Analysis of sugar concentration in fermentation medium}

The optimum concentration of sucrose as the carbon source was determined using a standard solution with the selected concentration (4-10 ppm); $1 \mathrm{~mL}$ of sucrose standard solution from each concentration was transferred into a test tube. Next, $1 \mathrm{~mL}$ of $5 \%$ phenol solution and $5 \mathrm{~mL}$ of concentrated $\mathrm{H}_{2} \mathrm{SO}_{4}$ solution were added. After $10 \mathrm{~min}$, the solution was homogenized by vortexing for $1 \mathrm{~min}$ at $6500 \mathrm{rpm}$ and then left to stand for $20 \mathrm{~min}$. The absorbance was then measured at a wavelength of $490 \mathrm{~nm}$ and the calibration curve was made using the absorbance obtained from each concentration [12].

For determining the concentration of sucrose in fermentation culture, the centrifuged fermentation culture was diluted up to 1000 times with distilled water; $1 \mathrm{~mL}$ of the solution was transferred into the reaction tube, and then, $1 \mathrm{~mL}$ of $5 \%$ phenol solution and $5 \mathrm{~mL}$ of $\mathrm{H}_{2} \mathrm{SO}_{4}$ solution were added. The solution was left to stand for $10 \mathrm{~min}$, homogenized, and then left to stand for an additional $20 \mathrm{~min}$. The absorbance was measured using UV-Vis spectrophotometer at $490 \mathrm{~nm}$. The obtained absorbance was plotted into the regression equation of the sucrose standard solution [13].

\section{RESULTS}

\section{Preparation}

\section{Culture maintenance and preculture}

After 7 days, green colonies of A. oryzae and A. tamarii covered the entire agar surface (Fig. 1). The PDA medium expressed a yellow cloudy color, 
which was originally a yellowish white. Each colony was inoculated in YES medium, and after preculturing for 2 days, white biomass pellet cells were obtained (Fig. 2).

\section{Screening of best mixed cultures}

The screening of fermentation cultures with $1 \% \mathrm{FeCl}_{3}$ solution is shown in Fig. 3. They expressed a similar brown color as in the sole culture, except the combination of A. oryzae A and A. tamarii A from IPBCC collection, which showed the most intensive brown color. The dry cell weight of each culture is shown in Table 1 . The results show that a combination of both molds is also the heaviest compared with other batch combinations $(42.20 \mathrm{~g} / \mathrm{L})$.

\section{Preparation of kojic acid standard calibration curve}

The standard absorbance spectrum of kojic acid was obtained by TLCdensitometer at a maximum wavelength of $318 \mathrm{~nm}$. The regression equation was obtained as $\mathrm{y}=-435.55+89.352 \mathrm{x}$ with $\mathrm{r}=0.9993$ (standard curve not shown).

\section{Optimization of fermentation conditions}

\section{Variation of carbon and nitrogen sources}

After the fermentation was completed ( 9 days), each fermentation culture was screened by the addition of $1 \% \mathrm{FeCl}_{3}$ solution, followed with the determination of kojic acid and dry cell weight (Table 2). The results of screening are shown in Figs. 4 and 5. The result shows that both sole cultures and mixed cultures produced the most intense brown color

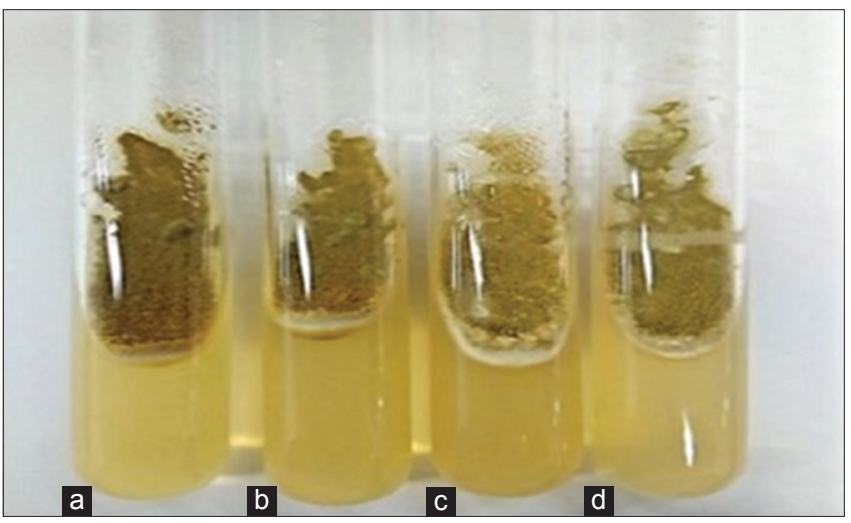

Fig. 1: Colonies of stock cultures incubated for $\mathbf{7}$ days (a) Aspergillus oryzae A; (b) A. oryzae B; (c) Aspergillus tamarii A; (d) A. tamarii B

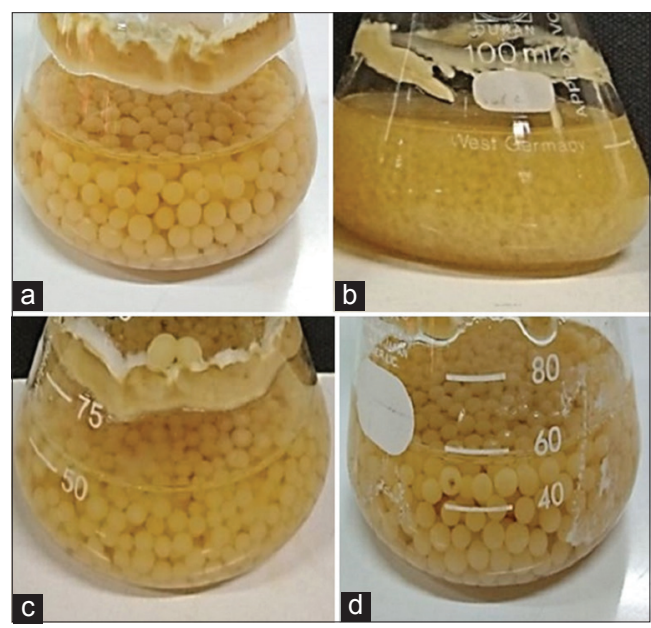

Fig. 2: Cell biomass after preculture for 2 days: (a) Aspergillus oryzae A; (b) A. oryzae B; (c) Aspergillus tamarii tamarii $\mathrm{A}$; (d) A. tamarii B with sucrose and yeast extract as substrate. Kojic acid determination was performed and is shown in Table 3. It shows that $2.6133 \mathrm{~g} / \mathrm{L}$ of kojic acid was produced in that substrate.

\section{Variation of $\mathrm{pH}$ medium}

From the data presented in Table 4, it can be seen that the medium with a $\mathrm{pH}$ of 3.5 produced kojic acid at a higher concentration $(2.6163 \mathrm{~g} / \mathrm{L})$ than the other media with different $\mathrm{pH}$ values. Based on the dry cell weight data in Table 4, a greater dry cell weight was obtained on the medium with a $\mathrm{pH}$ of 3.5 , indicating that the more acidic fermentation medium was a more ideal environment for microbial cell growth.

\section{Variation of inoculum concentration ratio}

The results in Table 5 show that a 2:3 ratio of inoculum A. oryzae:A. tamarii was more optimum than the other ratio which produced $2.8889 \mathrm{~g} / \mathrm{L}$ of kojic acid. Based on the dry cell weight data in Table 5, more cell biomass was obtained at that inoculum concentration ratio.

\section{Variation of aeration}

The results in Table 6 show that the amount of kojic acid produced from the medium with a $100 \mathrm{~mL}$ volume in a $250 \mathrm{~mL}$ Erlenmeyer flask was higher than that of the $50 \mathrm{~mL}$ volume of medium in $100 \mathrm{~mL}$ in a Erlenmeyer flask. However, based on the data of dry cell weight in Table 6, cell biomass in the $100 \mathrm{~mL}$ volume medium was less than cell biomass in the $50 \mathrm{~mL}$ volume medium.

\section{Qualitative analysis of kojic acid}

The standard solution of kojic acid with a concentration of $25.2 \mathrm{ppm}$ gave a maximum wavelength at $268.8 \mathrm{~nm}$ with an absorbance of 1.316 A (Fig. 6). Meanwhile, the kojic acid spectrum from the mixed cultures supernatant had the same maximum wavelength at $268.8 \mathrm{~nm}$ with absorbance at $1.163 \mathrm{~A}$. It shows that kojic acid was positively identified in the fermentation culture by spectrophotometry UV.

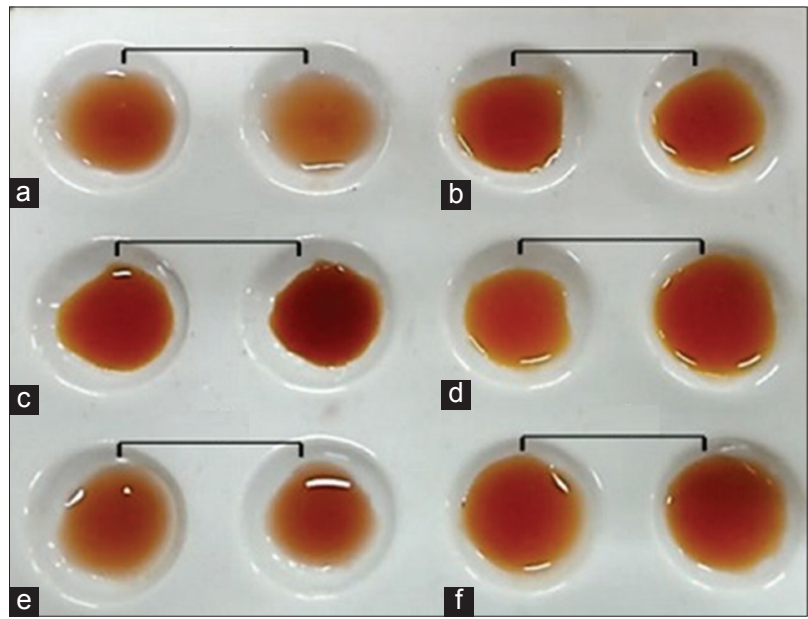

Fig. 3: Best mixed cultures screening: (a) Aspergillus oryzae $\mathrm{B}$ and Aspergillus tamarii $\mathrm{A}$; (b) A. oryzae $\mathrm{B}$ and $A$. tamarii $\mathrm{B}$; (c) A. oryzae A and A. tamarii A; (d) A. oryzae A and A.tamarii B; (e) A. oryzae A (comparison); (f) A. tamarii B (comparison)

Table 1: Dry cell weight determination of screening of best mixed cultures

\begin{tabular}{lll}
\hline No & Inoculum & Dry cell weight $\mathbf{( g / L )}$ \\
\hline 1 & A. oryzae A & 22.50 \\
2 & A. tamarii B & 30.25 \\
3 & A. oryzae A and A. tamarii A & 42.20 \\
4 & A. oryzae A and A. tamarii B & 27.50 \\
5 & A. oryzae B and A. tamarii A & 35.45 \\
6 & A. oryzae B and A. tamarii B & 12.85 \\
\hline
\end{tabular}

A. oryzae: Aspergillus oryzae, A. tamarii: Aspergillus tamari 
Table 2: Effect of fermentation medium on dry cell weight concentration

\begin{tabular}{|c|c|c|c|c|c|}
\hline \multicolumn{6}{|c|}{ Dry cell weight (g/L) } \\
\hline No & $\begin{array}{l}\text { Carbon source } \\
(50 \mathrm{~g} / \mathrm{L})\end{array}$ & $\begin{array}{l}\text { Nitrogen source } \\
(2,5 \mathrm{~g} / \mathrm{L})\end{array}$ & $\begin{array}{l}\text { A. oryzae } \\
\text { (comparison) }\end{array}$ & $\begin{array}{l}\text { A. tamarii } \\
\text { (comparison) }\end{array}$ & $\begin{array}{l}\text { A. oryzae and } \\
\text { A. tamarii }\end{array}$ \\
\hline 2 & Glucose & $\mathrm{CO}\left(\mathrm{NH}_{2}\right)_{2}$ & 8.638 & 8.942 & 8.606 \\
\hline 3 & Glucose & $\left(\mathrm{NH}_{4}\right)_{2} \mathrm{SO}_{4}$ & 10.53 & 10.732 & 10.09 \\
\hline 4 & Sucrose & Yeast extract & 13.508 & 13.726 & 14.908 \\
\hline 5 & Sucrose & $\mathrm{CO}\left(\mathrm{NH}_{2}\right)_{2}$ & 10.806 & 13.006 & 10.796 \\
\hline 6 & Sucrose & $\left(\mathrm{NH}_{4}\right)_{2} \mathrm{SO}_{4}$ & 13.692 & 9.602 & 11.128 \\
\hline 7 & Fructose & Yeast extract & 11.998 & 10.474 & 10.868 \\
\hline 8 & Fructose & $\mathrm{CO}\left(\mathrm{NH}_{2}\right)_{2}$ & 10.97 & 10.462 & 9.194 \\
\hline 9 & Fructose & $\left(\mathrm{NH}_{4}\right)_{2} \mathrm{SO}_{4}$ & 8.078 & 8.048 & 9.382 \\
\hline
\end{tabular}

A. oryzae: Aspergillus oryzae, A. tamarii: Aspergillus tamarii

Table 3: Effect of fermentation medium on kojic acid concentration

\begin{tabular}{|c|c|c|c|c|c|}
\hline \multicolumn{6}{|c|}{ Kojic acid concentration (g/L) } \\
\hline No & $\begin{array}{l}\text { Carbon source } \\
(50 \mathrm{~g} / \mathrm{L})\end{array}$ & $\begin{array}{l}\text { Nitrogen source } \\
(2,5 \mathrm{~g} / \mathrm{L})\end{array}$ & $\begin{array}{l}\text { A. oryzae } \\
\text { (comparison) }\end{array}$ & $\begin{array}{l}\text { A. tamarii } \\
\text { (comparison) }\end{array}$ & $\begin{array}{l}\text { A. oryzae and } \\
\text { A. tamarii }\end{array}$ \\
\hline 1 & Glucose & Yeast extract & 0.4337 & 0.4261 & 0.1051 \\
\hline 2 & Glucose & $\mathrm{CO}\left(\mathrm{NH}_{2}\right)_{2}$ & - & - & - \\
\hline 3 & Glucose & $\left(\mathrm{NH}_{4}\right)_{2} \mathrm{SO}_{4}$ & 0.3114 & 0.1292 & - \\
\hline 4 & Sucrose & Yeast extract & 1.4539 & 1.4844 & 2.6163 \\
\hline 5 & Sucrose & $\mathrm{CO}\left(\mathrm{NH}_{2}\right)_{2}$ & 0.1905 & 1.4349 & 0.2774 \\
\hline 6 & Sucrose & $\left(\mathrm{NH}_{4}\right)_{2} \mathrm{SO}_{4}$ & 0.4574 & - & 0.2195 \\
\hline 7 & Fructose & Yeast extract & 0.2042 & - & - \\
\hline 8 & Fructose & $\mathrm{CO}\left(\mathrm{NH}_{2}\right)_{2}$ & 0.1722 & 0.3471 & - \\
\hline 9 & Fructose & $\left(\mathrm{NH}_{4}\right)_{2} \mathrm{SO}_{4}$ & - & - & - \\
\hline
\end{tabular}

Table 4: Effect of pH of medium on kojic acid and dry cell weight concentration

\begin{tabular}{|c|c|c|c|c|}
\hline No & $\begin{array}{l}\text { pH of fermentation } \\
\text { medium }\end{array}$ & $\begin{array}{l}\text { A. oryzae } \\
\text { (comparison) }\end{array}$ & $\begin{array}{l}\text { A. tamarii } \\
\text { (comparison) }\end{array}$ & $\begin{array}{l}\text { A. oryzae and } \\
\text { A. tamarii }\end{array}$ \\
\hline \multicolumn{5}{|c|}{ Kojic acid concentration (g/L) } \\
\hline 1 & 3.5 & 1.4539 & 1.4844 & 2.6163 \\
\hline 2 & 4.5 & 1.7057 & 1.249 & 1.0274 \\
\hline 3 & 5.5 & 1.3195 & 2.7006 & 0.7970 \\
\hline \multicolumn{5}{|c|}{ Dry cell weight (g/L) } \\
\hline 1 & 3.5 & 13.508 & 13.726 & 14.908 \\
\hline 3 & 5.5 & 13.872 & 15.544 & 12.558 \\
\hline
\end{tabular}

A. oryzae: Aspergillus oryzae, A. tamarii: Aspergillus tamarii

Table 5: Effect of inoculum ratio on kojic acid and dry cell weight concentration

\begin{tabular}{llll}
\hline No & Inoculum & $\begin{array}{l}\text { Kojic acid } \\
\text { concentration (g/L) }\end{array}$ & $\begin{array}{l}\text { Dry cell } \\
\text { weight (g/L) }\end{array}$ \\
\hline 1 & A. oryzae (comparison) & 1.4637 & 13.508 \\
2 & A. tamarii (comparison) & 1.4751 & 13.726 \\
3 & A. oryzae + A. tamarii (1:1) & 2.6667 & 14.908 \\
4 & A. oryzae + A. tamarii (3:2) & 2.3110 & 14.53 \\
5 & A. oryzae + A. tamarii (2:3) & 2.8889 & 16.91 \\
\hline \multicolumn{4}{l}{ A. oryzae: Aspergillus oryzae, A. tamarii: Aspergillus tamarii }
\end{tabular}

When compared with the spectrocolorimetry result, the mixed cultures supernatant of fermentation gave a spectrum with a maximum wavelength at $503.6 \mathrm{~nm}$ which was similar to the standard solution of kojic acid of 100.8 ppm (data not shown).

Analysis of sugar concentration in fermentation medium

The regression equation of the standard solution of sucrose was: $y=-0.005+0.0682 x$ with $r=0.998$. Based on the data obtained in Table 7 , the yield value and productivity of kojic acid produced from mixed cultures of molds were higher than kojic acid produced from sole cultures. The yield value of kojic acid produced from mixed cultures of molds was $0.1396 \mathrm{gg}^{-1}$, with a productivity of $0.0304 \mathrm{gl} / \mathrm{h}$. Meanwhile, the yield value of kojic acid derived from the sole cultures was $0.0329 \mathrm{gg}^{-1}$, with a productivity of $0.0070 \mathrm{gl} / \mathrm{h}^{1}$ for $A$. oryzae, and the yield of kojic acid derived from $A$. tamarii was $0.1001 \mathrm{gg}^{-1}$ with the productivity of $0.0219 \mathrm{gl} / \mathrm{h}$. This suggests that the use of mixed cultures is more potent in the productivity of kojic acid than the use of sole cultures.

\section{DISCUSSION}

Green colonies of $A$. oryzae and $A$. tamarii that covered the entire agar surface were inoculated in YES medium. This stage aimed to obtain the optimum number and quality of the inoculum to quickly enter the growth phase during the fermentation process [8]. After preculture was performed with incubation for 2 days, white biomass pellet cells were obtained. A combination of A. oryzae and A. tamarii from IPBCC produced the heaviest cell biomass compared to other combinations and the sole cultures. It showed that microbial cells produced from the mixed cultures had the fastest growth which could increase the 
productivity of the secondary metabolites. Meanwhile, the screened supernatants expressed a reddish-brown color. This color formation indicated an oxidation reaction between $\mathrm{FeCl}_{3}$ and the $\mathrm{OH}$ group from kojic acid. The more intense the color formation, the more was the kojic acid production, which correlated with the weight of cell biomass. Therefore, A. oryzae and A. tamarii derived from the IPBCC collection were selected as the best mixed cultures for the fermentation process (Fig. 3c).

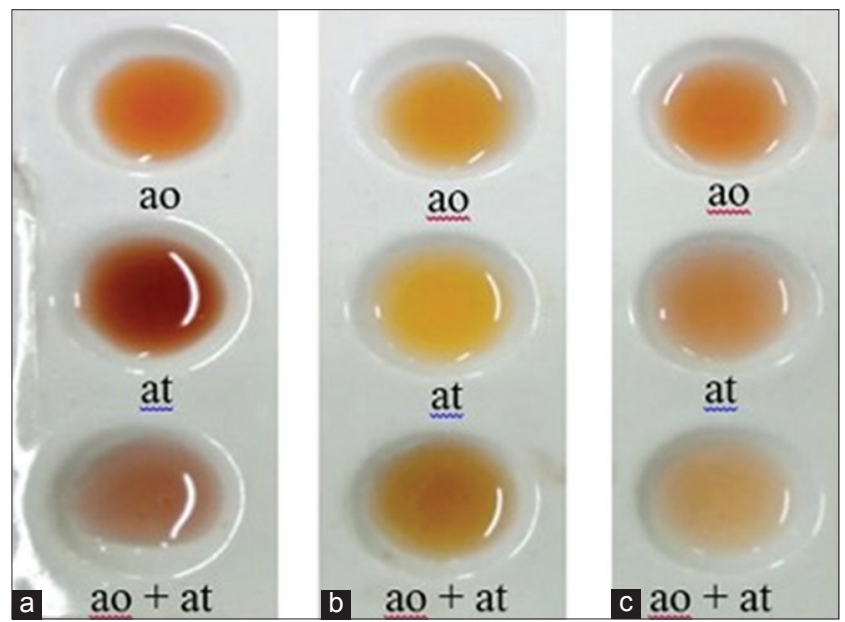

Fig. 4: Screening of fermentation medium with glucose as carbon source: (a) Yeast extract; (b) $\mathrm{CO}\left(\mathrm{NH}_{2}\right)_{2}$; (c) $\left(\mathrm{NH}_{4}\right)_{2} \mathrm{SO}_{4}$ as nitrogen source; ao = Aspergillus oryzae; at = Aspergillus tamarii; ao + at $=$ A. oryzae + A. tamarii

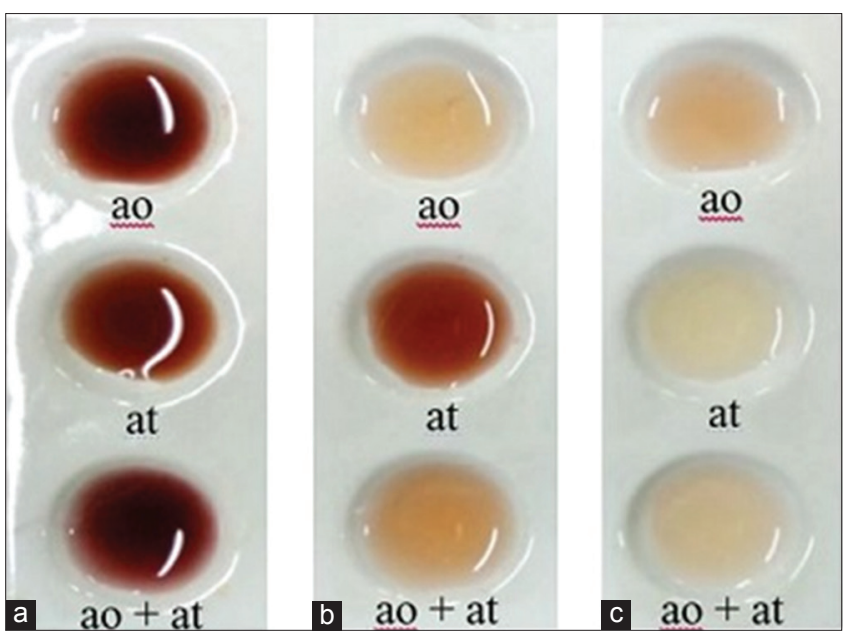

Fig. 5: Screening of fermentation medium with sucrose as carbon source: (a) Yeast extract; (b) $\mathrm{CO}\left(\mathrm{NH}_{2}\right)_{2}$; (c) $\left(\mathrm{NH}_{4}\right)_{2} \mathrm{SO}_{4}$ as nitrogen source; ao = Aspergillus oryzae; at = Aspergillus tamarii; ao + at $=$ A. oryzae + A. tamarii
The composition of fermentation medium can influence the supply of nutrients and cell metabolism. Carbon and nitrogen sources have dominant roles in fermentation processes because these nutrients are directly associated with the cell biomass and metabolite formation. In addition, the fermentation productivity depends on the culture medium used. Therefore, the substrates were optimized using three various carbon and nitrogen sources [14]. The results showed that sucrose and yeast extract was the optimum substrate to produce kojic acid and was therefore selected. Sucrose is a disaccharide which can be hydrolyzed to glucose and fructose. In kojic acid biosynthesis, these two monosaccharides act simultaneously: Glucose acts as a precursor of kojic acid and fructose contributes to microbial cell growth [15-17]. These findings were also demonstrated in another study that stated that yeast extract is a complex nitrogen source containing vitamins that can act as a precursor of kojic acid formation [18]. As can be seen in the dry cell weight data in Tables 2 and 3, obtained cell biomass was proportional to the concentration of kojic acid produced by each medium where the greater the weight of the dry cell, the more kojic acid was produced.

Medium $\mathrm{pH}$ was optimized with three various $\mathrm{pH}$ values, in which we found that a high amount of kojic acid was produced in a medium of $\mathrm{pH}$ 3.5. This correlates with an experiment which found that the optimum $\mathrm{pH}$ for the production of kojic acid depends on the type of carbon and nitrogen source used, where a $\mathrm{pH}$ in the range of 2-3 was the optimum when sucrose and yeast extract were used as a source of carbon and nitrogen [18].

Along with medium conditions, it was important to optimize inoculum concentrations of $A$. oryzae and $A$. tamarii to find which concentration has more potential in producing kojic acid. The results indicated that A. tamarii had a greater role than A. oryzae when both were combined. However, in this study, the growth curve of each mold could not be observed due to technical limitations, and optimum time for the growth of these two molds cells could not be determined.

Oxygen is necessarily required in aerobic fermentation processes. The mold cultures must be supplied with oxygen to satisfy the demand for growth. Oxygen and nutrients must be distributed uniformly by aeration and agitation. Aeration provides the required oxygen for microorganism growth, while agitation helps in mixing of the nutrients and also has a major role in microorganism growth [19]. This experiment showed that kojic acid from $100 \mathrm{~mL}$ medium was produced at a higher rate than the $50 \mathrm{~mL}$ medium; however, the cell biomass showed the opposite. Based on the concentration of kojic acid produced, the optimum aeration condition for kojic acid fermentation achieved was the medium with $100 \mathrm{~mL}$ volume in $250 \mathrm{~mL}$ flask, which was close to semi-aerobic conditions.

\section{CONCLUSION}

The best combination of fungi isolates for kojic acid fermentation was $A$. oryzae and A. tamarii from IPBCC. The best carbon and nitrogen source in this experiment was sucrose and yeast extract with a medium $\mathrm{pH}$ of 3.5. In addition, the best ratio of mixed cultures inoculum was $2: 3$ of A. oryzae and A. tamarii using $100 \mathrm{~mL}$ volume medium in $250 \mathrm{~mL}$

Table 6: Effect of aeration on kojic acid production and dry cell weight concentration

\begin{tabular}{lllc}
\hline No & $\begin{array}{l}\text { Volume of fermentation } \\
\text { medium (mL) }\end{array}$ & $\begin{array}{l}\text { A. oryzae } \\
\text { (comparison) }\end{array}$ & $\begin{array}{l}\text { A. tamarii } \\
\text { (comparison) }\end{array}$ \\
\hline Kojic acid concentration (g/L) & & \\
1 & 50 & 1.4634 & 1.4921 \\
2 & 100 & 1.5176 & 4.7202 \\
Dry cell weight (g/L) & 50 & & \\
1 & 100 & 13.537 & 13.759 \\
2 & 12.056 & 12.301 \\
\hline
\end{tabular}

A. oryzae: Aspergillus oryzae, A. tamarii: Aspergillus tamarii 


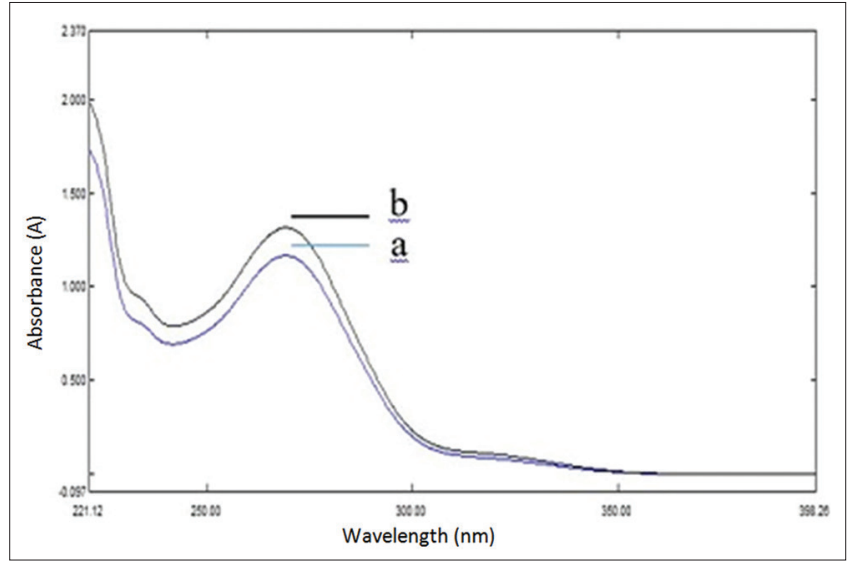

Fig. 6: Kojic acid spectrum on UV-Vis spectrophotometer: (a) Kojic acid from fermentation culture; (b) standard of kojic acid

Table 7: Yield and productivity of kojic acid from fermentation cultures

\begin{tabular}{lllll}
\hline Inoculum & Pmax (gL-1) & Yp/s (gg-1) & $\mathbf{t}(\mathbf{h})$ & $\mathbf{P}(\mathbf{g L} / \mathbf{h}-\mathbf{1})$ \\
\hline A. oryzae & 1.5176 & 0.0329 & 216 & 0.0070 \\
A. tamarii & 4.7202 & 0.1001 & 216 & 0.0219 \\
A. oryzae + A. tamarii & 6.5594 & 0.1396 & 216 & 0.0304 \\
\hline
\end{tabular}

A. oryzae: Aspergillus oryzae, A. tamarii: Aspergillus tamarii

Erlenmeyer flask. The yield value of kojic acid using mixed cultures was higher than that when using a sole culture.

\section{ACKNOWLEDGMENTS}

All authors acknowledge Universitas Indonesia for support and PITTA Research Grants 2017.

\section{CONFLICTS OF INTEREST}

Authors declare no conflicts of interest in this research.

\section{REFERENCES}

1. Rosfarizan M, Shamzi M, Nurashikin S, Madihah MS, Arbakariya BA. Kojic acid: Applications and development of fermentation process for production. Biotech Mol Biol Rev 2010;5:24-37.

2. Bentley R. From miso, sake and shoyu to cosmetics: A century of science for kojic acid. Nat Prod Rep 2006;23:1046.

3. Spencer A, Suhaili N, Bujang K, Hussaini A. Comparative Study of
Kojic Acid Production from Sago Hampas Using Different Strains of Aspergillus flavus via Solid State Fermentation. $2^{\text {nd }}$ ed. ASEAN Sago Symposium. Kota Samarahan, Sarawak, Malaysia: UNIMAS; 2012. p. 29-31.

4. Suryadi H, Radji M, Dianingtyas J, Hidayah AP. Improvement of Kojic Acid Production by a Mutant Strain of Aspergillus flavus, N40C10. Bandung: Presented at International Conference on Mathematics and Natural Sciences; 2006.

5. Velazhahan R. Bioprospecting of medicinal plants for detoxification of aflatoxins. Int J Nutr Pharmacol Neurol Dis 2017;7:60.

6. Pildain M, Frisvad J, Vaamonde G, Cabral D, Varga J, Samson R. Two novel aflatoxin-producing Aspergillus species from Argentinean peanuts. Int J Syst Evol Microbiol 2008;58:725-35.

7. Hassan HM, Saad M, Hazzaa MM, E Ibrahim AI. Optimization study for the production of kojic acid crystals by Aspergillus oryzae var. effusus NRC 14 Isolate. Int J Curr Microbiol Appl Sci 2014;3:133-42.

8. Sulistyaningrum L. Optimization of Kojic Acid Fermentation by Mutant Strain of Aspergillus flavus NTGA7A4UVE10 [Optimasi Fermentasi Asam Kojat Oleh Galur Mutan Aspergillus flavus NTGA7A4UVE10]. Thesis. Depok: Universitas Indonesia; 2008.

9. Sharma V, Garg M, Talukdar D, Thakur P, Henkel M, Sharma D, et al. Preservation of microbial spoilage of food by biosurfactant-based coating. Asian J Pharm Clin Res 2018;11:98-101.

10. Balaraman M, Ghatnur S, Parvatam G. Culture conditions for production of biomass, adenosine, and cordycepin from Cordyceps sinensis CS1197: Optimization by desirability function method. Pharmacog Mag 2015;11:448-56.

11. $\mathrm{Xu} \mathrm{C}, \mathrm{Hu}$ W, Liu S, Zhang Y, Xun D. Mycelial fermentation characteristics and antiproliferative activity of Phellinus vaninii ljup. Pharmacog Mag 2014; 10:430-4.

12. Dubois M, Gilles KA, Hamilton JK, Rebersss PA, Smith F. Colorimetric method for determination of sugars and related substances. Anal Chem 1956;28:350-6.

13. Suzanne NS. Introduction to the Chemical Analysis of Food. London: Jones and Bartlett Publisher; 1994. p. 137-64.

14. Aravindan R, Viruthagiri T, Seenivasan A, Subhagar S. Microbial production and biomedical applications of lovastatin. Indian J Pharm Sci 2008;70:701-9

15. Wan H, Chen C, Giridhar R, Chang T, Wu W. Repeated-batch production of kojic acid in a cell-retention fermenter using Aspergillus oryzae M3B9. J Ind Microbiol Biotechnol 2005;32:227-33.

16. Piantavini MS, Goncalves AG, Trindade AC, Merce AL, Potarolo R. Development and validation of a UV spectrophotometric method for kojic acid quantification based on its aluminum complexes. Asian J Pharm Clin Res 2013;1:70-3.

17. Mukul S, Surabhi K, Atul N. Cosmeceuticals for the skin: An overview. Asian J Pharm Clin Res 2011;4:1-6.

18. Kitada M, Ueyama H, Fukimbara T. Studies on kojic acid fermentation (i) cultural condition in submerged culture. J Ferment Technol 1967:45:1101-7.

19. Subrahmanyam V, Rao J, Kamath P, Raj P. Optimization of cultural conditions for protease production by a fungal Species. Indian J Pharm Sci 2010;72:161-6 